\title{
UPTAKE, TRANSLOCATION AND PERSISTANCE OF CARBENDAZIM IN COCONUT IN RELATION TO CONTROL OF STEM BLEEDING DISEASE
}

\author{
by \\ ANIL KUMAR ${ }^{1}$, K.K.N. NAMBIAR ${ }^{2}$ and S.R. VOLETI ${ }^{2}$
}

\begin{abstract}
Uptake, translocation and persistance of carbendazim in coconut in relation to control of stem bleeding caused by Thielaviopsis paradoxa was studied. The fungicide when applied through a single root @ 10g Bavistin/palm, was detected up to $2 \mathrm{~m}$ height in the trunk of treged palms on feeding side, whereas no fungicide was detected from remaining three sides. In the former case, the furigicide accumulated in sufficient concentrations to arrest the internal decay for six months. The residues detected in nut water from nuts of different maturity from treated adult palms (20 - $25 \mathrm{yrs}$.) were within safe limits.
\end{abstract}

\section{INTRODUCTION}

Stem bleeding in an important disease of coconut, reported from many countries (Menon and Pandalai, 1958; Nambiar and Sastry, 1988). Recently, involment of Thielaviopsis paradoxa (de Seynes) Von Hohnel as a primary causative agent of the disease was established (Nambiar et.al., 1986). The pathogen has been reported to be very sensitive to Bavistin 50WP (Carbendazim; methyl-2 - benzimidazole carbarnate; MBQ under in-vitro conclitions (Anon., 1986). Ad-hoc field control trials involving Bavistin application as one of the treatments have been reported to control the disease (Nambiar and Sastry, 1988). Therefore, a study on uptake, translocation and persistance of the fungicide in stem of coconut was undertaken so that the information can be used for better and effective control of the disease. Effect of the fungicide on viability of endoconidia and chlamydospores of the fungus was also studied.

\section{MATERIALS AND METHODS}

Adult palms (25-30 yrs.) of coconut were treated @ $0.5 \mathrm{~g}$ Bavistin/ $100 \mathrm{ml}$ water/palm and $10 \mathrm{~g}$ Bavistin $/ 100 \mathrm{ml} 0.5 \mathrm{~N} \mathrm{HCl} /$ palm by root feeding through a single young, functional and red-coloured root from the basin just below the surface soil. For the treatment at higher concentration, $10 \%$ suspension of Bavistin was prepared in $0.5 \mathrm{~N} \mathrm{HCl}$, filtered through Whatman No 1 filter paper and the filterate was used for root feeding.

To study the relationship between uptake of carbendazim and spiral arrangement of leaf scars on the coconut stem, two palms were fed through a single foot at higher concentration, just below a leaf scar on the lower protion of the stern. The stern samples $(2-3 \mathrm{~cm}$ deep) were taken from nodal area of marked leaf scar and subsequent five leaf scars such that the centre of the scar for sample no 1 and 6 were just above the point of root feeding. Six more stern samples were taken from internodal area, opposite to former sites of samplings. As uptake of the fungicide was found to be independent of the leaf scar arrangement (Table 3), no differentiation was made between nodal and internodal areas of the stem while taking stem samples in subsequent studies

For the translocation and persistance studies in the stern, the samples were taken from four sides of the treated palms at 1,2 and 3m stem height after 12, 20, 50, 120 and 180 days (both

\footnotetext{
${ }^{1}$ National Research Centre for Agroforestry, Jhansi-284 003 (U.P.).

${ }^{2}$ Central Plantation Crops Research Institute, Kasaragod-670 124, Kerala.
} 
concentrations). Samples of nut water from 4, 6 and 10 months old nuts were collected from four palms, treated @ $10 \mathrm{~g}$ Bavistin/palm after 1, 8, 23 and 30 days for residue analysis. In another experiment, bunches having 6 months old nuts were makred in 3 palms and feeding was done from the marked bunch side and nut samples were taken after 1, 8, 15 and 30 days. The samples were analysed for presence of carbendazim by using bioassay method.

Bioassay tests were performed against $\underline{T}$. paradoxa by using food poison technique. For analysis of the stern samples the tissue was squeezed to get 2-3 ml extract in culture tubes. The extract was sterilized after adding agar powder (2\%). Slants were prepared and inoculated with $4 \mathrm{~mm}$ mycelial disc of the text fungus. Observations on fungal growth on slant medium were recorded after 3 days of incubation at $30^{\circ} \mathrm{C}$. Presence of carbendazim in stern was also determined by artifically inoculating the treated palms at both concentrations with $\mathrm{T}$. paradoxa by bore hole method (Nambiar et.al., 1986). Palms were inoculated at 1 . and $2 \mathrm{~m}$ height on feeding and opposite sides to feeding site, just after complete uptake of the fungicide. Observation on external, bleeding and extent of internal decay were recorded after 20 days and 7 months, respectively. For analysis of nut water samples, the nut water was sterilized after adding agar power at $2 \%$, the medium was poured in sterile plates and inoculated with the test fungus, Colony diameter was recorded after an incubation of $40 \mathrm{hrs}$ at $30^{\circ} \mathrm{C}$. Quantification of the fungicide was done by using standard dose response curve (Fig.la).

To study the effect of Bavistin on endoconidia and chlarnydo spores of the fungus, spores were soaked at different concentrations $(1,2,5,10,50$ and $100 \mathrm{ppm})$ for 7,15 and 30 days and washed thrice with distilled water by centri-fugation. Viability of the washed spores was checked by germination test (Mather and Ravenscroft, 1966), performed on sugarcane juice agar medium (200 $\mathrm{ml}$ sugargane juice, $20 \mathrm{~g}$ agar and $800 \mathrm{ml}$ distilled water; $\mathrm{pH} 4.5$ ).

\section{RESULTS AND DISCUSSION}

T. paradoxa was found suitable as test organism for bioassay of carbendazim with a low ED50 value of $0.057 \mathrm{ppm}$. Carbenciazim could be quantified in nut water using standard dose response curve (Fig. 1a). Autoclaving of the samples did not affect the sensitivity of the assay (Fig. lb).

Good growth of the test fungus was noticed on control stern extract agar slants (containing no fungicide) within $24 \mathrm{hrs}$. Absence of growth of the fungus on test slants for 3 days was recorded for positive presence of carbendazim (Table 1). As per sensitivity of the assay, the samples with positive response had the fungicide at concentrations ? $0.5 \mathrm{ppm}$ (Table 1).

No phytotoxic symptorns were noticed.on pdlms troated with acidic extract $(0.5 \mathrm{~N} \mathrm{HCI})$ of, Bavistin. The recovery of carten dazim from the fungicidal suspension in $0.5 \mathrm{~N} \mathrm{HCI}$ was determined spectrophotometrically and was found to be quantitative. The solubility of carbenclazim showed a sharp increase with increase in H-ion concentration, below pH 3.0 (Table 2).

The data on cletection of carbenclazim in stern samples taken from nodal and intermodal areas are presented in Table 3. The fungicide was cletected only in samples taken from feeding side, while no fungicide was traced in samples taken from remaining three sides irrespective of nature of the stern tissue sampled (nodal and internodal area). This indicates that the translocation of carbendazim in coconut stern is indepenclent of the spiral arrangement of the leaf scars. The results on persistance of the fungicide in stern (Table 4) further confirm the finding. On feeding side, the chernical was cletected at Im height for 20 days in palms treated @ 0.05 Bavistin/palm and at $2 \mathrm{~m}$ for 180 days in palms treated@10g Bavistin/palm. The observations made on disease development in the treated palms after artificial inoculation with $\underline{T}$. paradoxa are also in agreement with the above mentioned results (Table 5). The external bleeding symptorns were recorded in ail treatments except one. Palms 
treated @10g Bavistin did not exhibit the symptom at $\mathrm{lm}$ height on the feeding side, while it was noticed in ail other treatments. Extent of intermal decay at 1 and $2 \mathrm{~m}$, on feeding side in palms treated with higher concentration was less as compared to other treatments. The intermal decay at ail inoculation sites, in palms treated at lower concentration was at par with the decay in control (untreated) palms.

The results on effect of Bavistin soaking on endoconidia and chlamyclo spores showed that the treatments at concentrations tested i.e. 1-100 ppm, were not lethal to the spores. Good germination $(90 \%)$ was recorded after various treatments. The rate of germ tube growth of spores treated at 1-2 ppm was normal, while it was slower for spores treated at 5-100 ppm. However, the spores treated at higher concentrations also grew into normal. colonies after a short lag period. The results on residue analysis in nut water from seven palms (root fed @10g Bavistin) showed that the fungicide accumulated to detectable level only in ohe palm. The detected concentrations in this palm in nut water of 4, 6 and 10 months old nuts were respectively $0.0,0.28$ and $0.5 \mathrm{ppm}$ after 1 day and 0.19 , 0.47 and $0.17 \mathrm{ppm}$ after 8 days of treatment. The chemical was not detected in above mentioned samples after 23 and 30 days of the treatment.

From the above results following conclusions could be drawn: i) Translocation of carbendazim in stem of coconut palms is independent of the spiral arrangement of leaf scars on it. In palms, treated @ 0.5g Bavistin/palm the uptake and persistance of the fungicide is too low to give any protection against the disease. The buils up of fungicide concentration in palms, treated @ $10 \mathrm{~g}$ Babistin/pal is sufficient to protect it up to $1-2 \mathrm{~m}$ on the feeding side for six month. The pathogen is known to colonize the host stem all around and in severe cases, the infection goes up to stem apex (Menon and Pandalai, 1958). Hence, the fungicidal treatment at the higher concentration fs likely to be effective only in palms that are in early stages of disease development (having leasions up to $1-2 \mathrm{~m}$ height). Palms having lesions all around should be root fed at more than one site, ii) Present study shows that the effect of fungicide on the spores is fungistatic. Therefore, repeated fungicidal application may be required for prolonged control, and iii) The fungicide does not accumulate in harmful proportions in nut water of nuts of different maturity from 20-25 yrs old palms as per toxicological limits set for certain other edible commodities (Annon., 1974).

\section{ACKNOWLEDGEMENTS}

The authors are thankful to Dr. M.K. Nair, the Director, CPCRI, Kasaragod for providing encouragement and facilities and Dr. (Mrs.) Rohini Iyer for going through the manuscript. 


\section{REFERENCES}

ANONYMOUS. 1974. Bavistin. BASF Aktiengesell schaft Agricultural Research Station, Limburgerhof, W. Germany. pp. 11.

ANONYMOUS. 1986. Annual Report. Central Plantation Crops Research Institute, Kasaragod, India. pp. 19.

MATHRE, D.E. and RAVENSCROFT, A.V. 1966. Physiology of germination of endoconial of Thielaviopsis basicola. Phytopathology 56 : 337-342.

MENON, K.P.V. and PANDALAI, K.M. 1958.1he Coconut Palm - a Monograph, Indian Central Coconut Committee, Ernakulum, pp. 384.

NAMBIAR, K.K.N., JOSHI, Y., VENUGOPAL, M.N. and CHANDRAMOHAN, R. 1986. Stem bleeding disease of coconut : Reproduction of symptorns by inoculation with Thielaviopsis paradoxa. J. Plantation Crops 14 (2) : 130-133.

NAMBIAR, K.K.N. and SASTRY, R.K. 1988. Stern bleeding disease of coconut : Current status and approaches for its control. Philippine J. Coconut Studies $13: 30-32$. 
Table 1. Relationship between inhibition of T. paradoxa growth and carbendazim concentration in coconut stem extract agar slants

\begin{tabular}{|c|c|c|c|c|}
\hline \multirow{2}{*}{$\begin{array}{c}\text { Concentration* of } \\
\text { carbendazim (Ppm) }\end{array}$} & \multicolumn{5}{|c|}{ Observation on fungal growth ${ }^{\circledR}$ after } \\
\cline { 2 - 5 } & 1 day & 2 days & 3 days & 7 days \\
\hline Control & + & + & + & + \\
0.1 & + & + & + & + \\
0.2 & - & + & + & + \\
0.5 & - & - & - & + \\
1.0 & - & - & - & - \\
\hline
\end{tabular}

* Desired concentrations were achieved by mixing $1 \mathrm{ml}$ stem extract from an untreated palm and $1 \mathrm{ml}$ fungicidal suspension of appropriate concentration.

@ Observations on fungal growth were recorded as (-) for positive growth and (-) for no growth.

Table 2. Effect of pH on solubility of carbendazim

\begin{tabular}{|c|c|}
\hline $\mathrm{pH}$ & Solubility $(\mathrm{mg} / 100 \mathrm{ml})$ \\
\hline 7.6 & 1.0 \\
5.7 & 1.3 \\
5.0 & 1.8 \\
4.0 & 3.6 \\
3.1 & 19.0 \\
2.2 & 180.0 \\
1.0 & $1,650.0$ \\
$0.0(1 \mathrm{~N} \mathrm{HCL})$ & $>7,500.0$ \\
\hline
\end{tabular}

Table 3: Detection of carbendazim in stem samples (after 20 days of treatment) taken from Nodal and inter-nodal areas of palm treated @ 10g. Bavistin/palm

\begin{tabular}{|c|c|c|c|c|c|c|c|c|c|c|}
\hline \multirow{3}{*}{$\begin{array}{c}\text { Sample } \\
\text { No. }\end{array}$} & \multicolumn{5}{|c|}{ Palm No. I (right handed-crown) } & \multicolumn{5}{|c|}{ Palm No. II (left handed crown) } \\
\hline & \multirow{2}{*}{$\begin{array}{c}\text { Ht. of } \\
\text { Sampling } \\
(\mathrm{cm})\end{array}$} & \multicolumn{2}{|c|}{ Nodal area } & \multicolumn{2}{|c|}{ Inter-nodal area } & \multirow{2}{*}{$\begin{array}{c}\text { Ht.of } \\
\text { Sampling } \\
\text { (cm) }\end{array}$} & \multicolumn{2}{|c|}{ Nodal area } & \multicolumn{2}{|c|}{ Inter-nodal area } \\
\hline & & $\begin{array}{l}\text { Assay } \\
\text { reaction }\end{array}$ & $\begin{array}{l}\text { Angle } \\
\text { with } \\
\text { line of } \\
\text { feeding }\end{array}$ & $\begin{array}{l}\text { Assay } \\
\text { reaction }\end{array}$ & $\begin{array}{c}\text { Angle } \\
\text { with } \\
\text { line of } \\
\text { feeding } \\
\end{array}$ & & $\begin{array}{c}\text { Assay } \\
\text { reaction }\end{array}$ & $\begin{array}{l}\text { Angle } \\
\text { with } \\
\text { line of } \\
\text { feeding }\end{array}$ & $\begin{array}{l}\text { Assay } \\
\text { reaction }\end{array}$ & $\begin{array}{c}\text { Angle } \\
\text { with } \\
\text { line of } \\
\text { feeding } \\
\end{array}$ \\
\hline 1. & 74 & + & 00.0 & & 180.0 & 55 & + & 00.0 & - & 180.0 \\
\hline 2. & 81 & - & +150.4 & + & -29.6 & 61 & & -120.6 & - & +51.4 \\
\hline 3. & 88 & - & -59.2 & - & +120.8 & 67 & - & +88.2 & - & -91.8 \\
\hline 4. & 96 & - & +68.4 & - & -111.6 & 73 & - & -47.8 & - & +132.2 \\
\hline 5. & 103 & - & -141.3 & - & +39.7 & 79 & - & +128.6 & - & -51.4 \\
\hline 6. & 110 & + & 00.0 & & 180.0 & 86 & + & 00.0 & - & 180.0 \\
\hline
\end{tabular}


Table 4. Detection of carbendazim in stern samples from feeding side after different periods

\begin{tabular}{|l|c|c|c|c|c|c|}
\hline \multirow{2}{*}{$\begin{array}{c}\text { Amount of carbendazim } \\
\text { fed/palm/root }\end{array}$} & \multirow{2}{*}{$\begin{array}{c}\text { Height of } \\
\text { sampling }\end{array}$} & \multicolumn{5}{|c|}{ Detection of carbendazim ${ }^{\circledR}$ in samples taken after (days) } \\
\cline { 3 - 7 } $0.5 \mathrm{~g}$ Bavistin 50 WP & $1 \mathrm{~m}$ & + & + & - & - & - \\
& $2 \mathrm{~m}$ & - & - & - & - & - \\
& $3 \mathrm{~m}$ & - & - & - & - & - \\
5.0 g Carbendazim & $1 \mathrm{~m}$ & + & + & + & + & + \\
$(=10 \mathrm{~g}$ Bavistin) & $2 \mathrm{~m}$ & - & + & + & + & + \\
& $3 \mathrm{~m}$ & - & - & - & - & - \\
\hline
\end{tabular}

The observations are based on three palms ppr treatment.

@ (+) fungicide present (-) fungicide absent.

Table 5. Effect of carbendazim, fed through a single root on symptom expression of stem bleeding of coconut after artificial inoculation with $\underline{\mathbf{T} \text {. paradoxa. }}$

\begin{tabular}{|c|c|c|c|c|c|}
\hline \multirow{2}{*}{$\begin{array}{l}\text { Amount of carbenclazim } \\
\text { fed/palm/root }\end{array}$} & \multirow{2}{*}{$\begin{array}{l}\text { Height of } \\
\text { inoculation } \\
\text { of pathogen }\end{array}$} & \multicolumn{2}{|c|}{$\begin{array}{l}\text { Presence @ of bleeding at } \\
\text { inoculation site after } 20 \text { days }\end{array}$} & \multicolumn{2}{|c|}{$\begin{array}{l}\text { Lesion size after } 7 \text { months } \\
(\mathrm{mm} \times \mathrm{mm})\end{array}$} \\
\hline & & Feeding Side & $\begin{array}{r}\text { Opposite to } \\
\text { feeding side }\end{array}$ & Feeding side & $\begin{array}{r}\text { Opposite to } \\
\text { feeding side }\end{array}$ \\
\hline \multirow[t]{2}{*}{$0.5 \mathrm{~g}$ Bavistin 50WP } & $1 \mathrm{~m}$ & + & + & $50 \times 29$ & $52 \times 28$ \\
\hline & $2 m$ & + & + & $67 \times 35$ & $65 \times 26$ \\
\hline \multirow[t]{2}{*}{ 5.0g Carbendazim } & $1 \mathrm{~m}$ & - & + & $20 \times 23$ & $49 \times 25$ \\
\hline & $2 m$ & + & + & $37 \times 28$ & $56 \times 24$ \\
\hline \multirow[t]{2}{*}{ Control (Untreated palms) } & $1 \mathrm{~m}$ & + & + & $49 \times 28$ & - \\
\hline & $2 \mathrm{~m}$ & + & + & $67 \times 30$ & - \\
\hline
\end{tabular}

Observations are based on two palms per treatment.

@ (+) bleeding present and (-) bleeding absent.

\section{Legend to the Fig. 1}

Relationship between percent inhibition of radial growth of T. paradoxa colonies on nut water agar and concentration of carbendazim a) concentration (logrithmic) and percent inhibition (probit) and b) concentration (arithmatic) and percent inhibition (arithmatic) when the fungicide was added before - ) and after ( o o ) sterlization of the medium. 